\title{
The use of superior varieties to increase rice yields in lowland irrigated of Southeast Sulawesi
}

\author{
Muhammad Alwi Mustaha*, Cipto Nugroho, Samrin, and Dian Rahmawati \\ Assessment Institute for Agricultural Technology of Southeast Sulawesi, Kendari, Southeast \\ Sulawesi, Indonesia
}

\begin{abstract}
In order to increase national rice production, the Ministry of Agriculture has released some high yielding varieties. The research was aimed to obtain superior rice varieties adapted to irrigated lowland agroecosystems of Southeast Sulawesi. In the first planting season, research was carried out in Olo-oloho Village, Uepai sub district and the second season at the Wawotobi Experimental Garden. Eight varieties were tested, .i.e. Inpari 31, Inpari 34, Inpari 35, Inpari 38, Inpari 39, Inpari 41, Inpari 42, Inpari 43 and Mekongga. The variables observed were growth, yield and pest and disease dynamics. The results shows that there was variation growth and yield of the tested varieties. The growth and yield also varied depend on the season. In the first planting season, Inpari 34 and Inpari 43 showed better growth than others, but Inpari 31 resulted the highest rice yield $(4.83 \mathrm{t} / \mathrm{ha})$. In the second planting season, only Inpari 34 showed consistent growth, but the variety that had showed the highest yield was Inpari 43 (8.13 t/ha).
\end{abstract}

\section{Introduction}

A number of agricultural development programs has been issued by the government but is constrained due to a number of problems such as the limited agricultural resources, both in quality and quantity, especially land, water, vegetation, and human resources. Meanwhile, the risk of agricultural production also increased significantly due to the increased diversity of global climate change on flooding, drought, and increased attack of plant pest organisms.

The impact of climate change is very visible in the food crop sub-sector, such as the occurrence of floods, droughts and increased pest attacks, decreased yields and production quality. The Southeast Sulawesi region is also affected by the impacts of climate change. In 2013 , it was known that the main disease of lowland rice was blast with an attack area of 2,414 ha [1] and the results of blast monitoring in Konawe Regency reached 40.25\% [2]. This condition needs serious attention to prevent its spread. The BPTPH report [3] stated that for the period October-March 2015/2016 and 2016/2017, the dominant pests were rats, stem borer, blast, and bacterial leaf blight. However, it is interesting to observe the emergence of brown planthoppers in the Padangguni and North Tongauna areas, Konawe

* Corresponding author: alwi_mustaha@yahoo.com 
Regency during the $2016 / 2017$ period. This is thought to be due to the impact of climate change, particularly the occurrence of the la nina effect or commonly known as the wet dry season.

The support of land resources, which is still quite extensive, allows Southeast Sulawesi to have the opportunity to contribute greatly to efforts to achieve rice self-sufficiency. The Southeast Sulawesi Food Crops and Livestock Service report [4], the potential of rice fields is 350,000 ha, where functional rice fields are 132,648 ha, meaning there is still a potential of about 217,352 ha that can be developed into rice fields through new rice field printing efforts that are currently encouraged to encourage increased production. From the functional land area above, it is divided into 102,776 ha of irrigated paddy fields, 26,283 ha of rainfed paddy fields, 3,168 ha of tidal swamp land and the remaining 421 ha of lebak swampland.

Data from the Agriculture Department, the development of harvested area, production and productivity of rice for 5 years (2012-2016) in Southeast Sulawesi, where the average harvested area is 142,348 ha, production is 618,588 tons and productivity is $43.55 \mathrm{ku} / \mathrm{ha}$ [5]. It seems that this achievement can still be improved because from several studies it can be achieved 6-7 t/ha [1,6,7]. The Result gap because the application of technology is not optimal, the impact of climate change and land resource constraints. Report of Abidin et al. [8], that the availability of quality seeds, the use of fertilizers, pest attacks and the availability of water are the main problems of lowland rice in Southeast Sulawesi.

Changes in rainfall patterns and an increase in temperature also cause a decrease in production, while the indirect impact is a change in the dynamics of pest/disease attacks [9]. Climate change and improper cultivation are one of the triggers for pests such as blast, bacterial leaf blight and others. Specifically, it is related to blast attack in the vegetative phase causing the plant to die and during the generative phase causing the panicle neck and empty rice grains to be broken [10]. Therefore, integrated control is needed such as the use and rotation of varieties, cultivation techniques, and chemical approaches. There are research results that show the best technology package for controlling blast disease, namely the planting of jajar legowo; application of $\mathrm{N}$ fertilization based on local recommendations of 50 to $100 \%$, and control with systemic fungicides in a controlled manner [11]. Rice cultivation throughout the year creates a conducive environment for disease development and to control it must be accompanied by alternation of varieties or even gene rotation [12].

Improvement of cultivation techniques begins with the use of seeds or varieties with superior characters, especially yield potential and resistance to biotic and abiotic environments. The target of varietal improvement is to produce new varieties with superior characteristics in each regional typology, namely: rice fields, highlands, upland, deep water and tidal fields [13]. Ciherang is the most popular variety and currently it is known that a number of varieties have the prospect of replacing these varieties and at the same time providing choices for farmers, namely Inpari 18, Inpari 19, and Inpari Sidenuk. According to the research results of Sularno et al. [14], the use of the Inpari 13 variety can increase productivity by $33.92 \%$ and increase net profit by $56.57 \%$.

Based on these conditions, it is necessary to study the use of superior varieties of rice seeds that are adaptive to the agro-ecosystem of irrigation rice fields and climate change in Southeast Sulawesi.

\section{Materials and methods}

The experiment was conducted in two growing seasons (rainy season and dry season) on 2017 in Konawe Regency, Southeast Sulawesi. The study was arranged using a randomized block design (RBD) with rice varieties as the treatment. Nine high yield varieties used are 
Inpari 31, Inpari 34, Inpari 35, Inpari 38, Inpari 39, Inpari 41, Inpari 42, Inpari 43, and Mekongga. Each treatment was repeated 5 times. The plot size of each treatment is $10 \mathrm{~m} \mathrm{x}$ $10 \mathrm{~m}$, thus the area of land used for research is $4,500 \mathrm{~m}^{2}$. Planting system using a 2:1 rows based on an integrated crop management.

Parameters measured consisted of plant height, number of tillers per clump, number of productive tillers, trunk weight, number and length of panicles, weight of 1000 grains. All the vegetative parameters were measured at $30 \mathrm{DAP}, 60 \mathrm{DAP}$, and before harvest. The number of productive tillers was counted as all tillers that produced panicles just before harvest. The weight of the trunk was weighed at harvest. The number of panicles counted is the panicles formed at harvest. Panicle length was measured from the base to the tip of the panicle at harvest. Crop yield was measured using sampling method, where the sample size was $3 \mathrm{~m} \mathrm{x} 4 \mathrm{~m}$. Weight of 1,000 grains, calculated by the formulation:

$$
\mathrm{B} 1000 \mathrm{~B}=[\mathrm{A} \times\{(100-\mathrm{B}) / 86\}]
$$

$$
\begin{array}{ll}
\mathrm{B} 1000 \mathrm{~B} & =\text { weight of } 1000 \text { grain at } 14 \% \text { moisture content } \\
\mathrm{A} & =\text { weight of } 1000 \text { grain at water content } \mathrm{B} \\
\mathrm{B} & =\text { measured water content }
\end{array}
$$

The production of dry milled grain $(\mathrm{GKG})$ was calculated by the formulation:

$$
\mathrm{H}=[\{(\mathrm{A}) \times(10,000) / \mathrm{B}\} \times(100-\mathrm{C} / 86)]
$$

$\mathrm{H}=$ Yield of grain per hectare at $14 \%$ moisture content

A $\quad=$ Net grain yield from a net plot of B $\mathrm{m} 2$ with a water content of $\mathrm{C}$

B $\quad=$ Net plot area

$\mathrm{C}=$ Measurable moisture content of the net plot of grain

The intensity of pests and diseases attack (IS) was calculated by the formula developed by the Directorate General of Food Crop Protection (2008), as follows:

$$
\text { IS }=\frac{\text { Number of affected (clumps/plant parts) }}{\text { Total number of plants (clumps, stems observed) }}
$$

The attack intensity categories for the plant pest group were: $0-25 \%$ (mild), $26-50 \%$ (moderate), $51-90 \%$ (severe) and $>91 \%$ (very severe). Meanwhile, the attack intensity categories for the plant disease group were as follows: $<11 \%$ (mild), 11-25\% (moderate), $25-75 \%$ (severe) and $75-100 \%$ (very severe). All the collected data were analyzed using analysis of variance (ANOVA).

\section{Results and Discussion}

\subsection{Soil Physical and chemical characteristics}

Table 1 shows physical and chemical characteristics of the research site soil. Soil conditions of the two research sites were relatively similar. The soil $\mathrm{pH}$ was relatively low, which cause nutrient availability also low. However, those exchangeable cations were classified high to very high. Based on this condition, it is recommended to use organic fertilizers and lime to increase soil $\mathrm{pH}$, as well as inorganic fertilizers to increase soil productivity. 
Table 1. Physical and chemical characteristics of the study site for lowland rice

\begin{tabular}{|c|c|c|c|}
\hline \multirow{2}{*}{ No } & \multirow{2}{*}{ Description } & \multicolumn{2}{|c|}{ Study location (District) } \\
\cline { 3 - 4 } & & Olo-oloho & Wawotobi \\
\hline 1. & $\mathrm{pH} \mathrm{H} \mathrm{H}_{2} \mathrm{O}$ & $5,47(\mathrm{~A})$ & $5,01(\mathrm{~A})$ \\
\hline 2. & $\mathrm{pH} \mathrm{KCl}$ & 4,42 & 3,72 \\
\hline 3. & $\mathrm{C}$-organic $(\%)$ & $0,87(\mathrm{VL})$ & $1,35(\mathrm{~L})$ \\
\hline 4. & $\mathrm{~N}$-organic (\%) & $0,72(\mathrm{VL})$ & $0,86(\mathrm{VL})$ \\
\hline 5. & $\mathrm{C} / \mathrm{N} \mathrm{Ratio}$ & $1,20(\mathrm{VL})$ & $1,56(\mathrm{VL})$ \\
\hline 6. & $\mathrm{P}_{2} \mathrm{O}_{5}$ Bray $1(\mathrm{ppm})$ & $5,58(\mathrm{VL})$ & $4,96(\mathrm{VL})$ \\
\hline 7. & $\mathrm{~K} 2 \mathrm{O} \mathrm{HCl} 25 \%(\mathrm{me} / 100 \mathrm{~g})$ & $18,02(\mathrm{~L})$ & $13,53(\mathrm{~L})$ \\
\hline 8. & Exchangeable $\mathrm{Ca}(\mathrm{me} / 100 \mathrm{~g})$ & $15,16(\mathrm{H})$ & $12,62(\mathrm{H})$ \\
\hline 9. & Exchangeable $\mathrm{Mg}(\mathrm{me} / 100 \mathrm{~g})$ & $6,74(\mathrm{H})$ & $4,54(\mathrm{H})$ \\
\hline 10. & Exchangeable $\mathrm{K}(\mathrm{me} / 100 \mathrm{~g})$ & $3,31(\mathrm{VH})$ & $2,96(\mathrm{VH})$ \\
\hline 11. & Exchangeable $\mathrm{Na}(\mathrm{me} / 100 \mathrm{~g})$ & $5,95(\mathrm{VH})$ & $5,35(\mathrm{VH})$ \\
\hline 12. & Cation exchange capacity $(\mathrm{CEC})$ & $19,41(\mathrm{M})$ & $22,26(\mathrm{M})$ \\
\hline 13. & Base saturation $(\%)$ & $17,10(\mathrm{VL})$ & $12,46(\mathrm{VL})$ \\
\hline
\end{tabular}

Note: analyzed at UHO Laboratory (2017)

pH H2O: 4.5 - 5.5 classified as acid(A)

Grades: very low (VL), Low (L), moderate $(\mathrm{M})$, high $(\mathrm{H})$ and very high $(\mathrm{VH})$

\subsection{Climatic conditions}

Figure 1 and 2 is presenting rainfall pattern in the two research locations. The rainy period occurs in 8 months between December to July, and only 4 months that categorized as dry period. According to the Köppen-Geiger climate classification, the climatic conditions in the research sites was Af. The average annual temperature is $27^{\circ} \mathrm{C}$. The driest month is October. The peak of the rainy season falls in March-April.

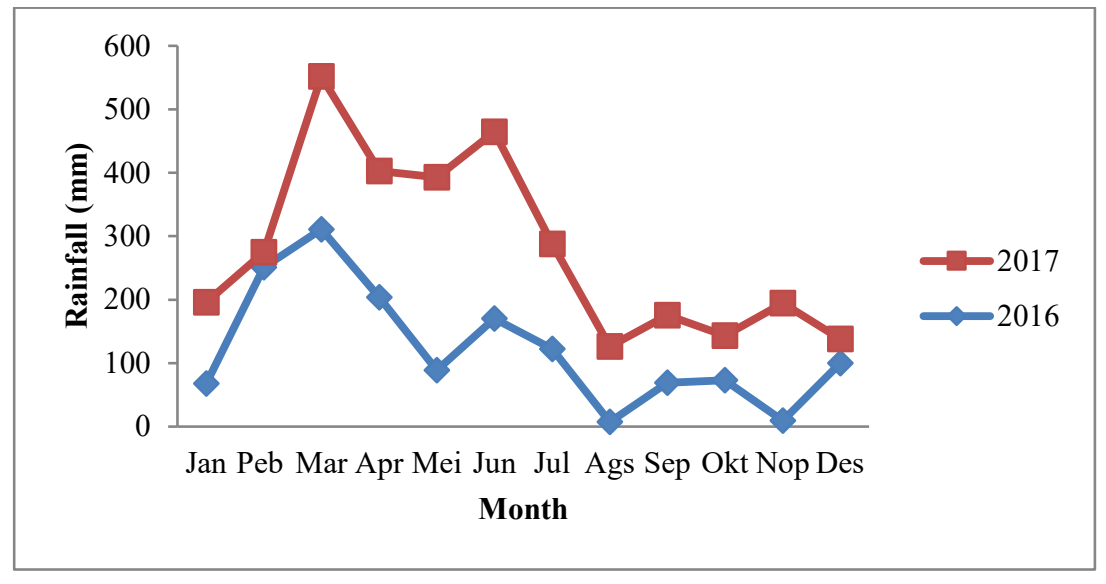

Fig. 1. Rainfall in Uepai District, Konawe Regency 2016-2017 


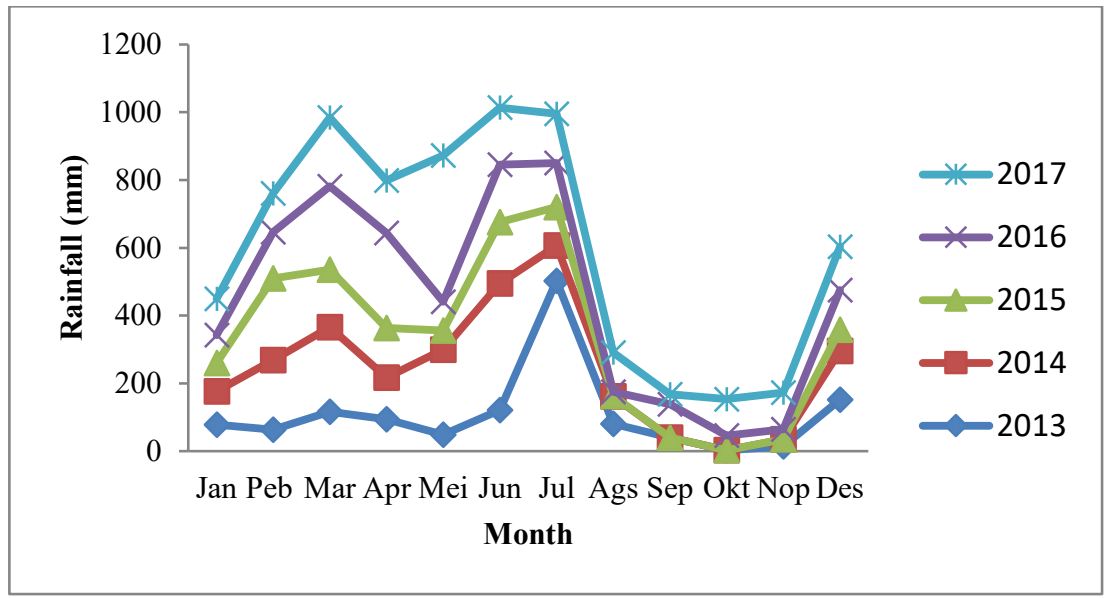

Fig. 2. Rainfall in Lalosabila Village, Wawotobi District, Konawe Regency 2013-2017

\subsection{Rice growth and yield}

Rice growth in the first planting season varied among the varieties tested (Table 2). This may be due to the characteristics of each variety. Plant height of Inpari 34 was $123.33 \mathrm{~cm}$, higher than other varieties; however numbers of tillers at 75 DAP was lower than other varieties. Inpari 43 had 16.10 tillers per plant, the most in number of tillers compared to other varieties.

Parameters of yield components measured were number and length of panicles, number of filled grain, weight of 1000 grains and yield (Table 3). The number of grains per panicle is determined by variety and stand density, while number of filled grain was determined the environmental conditions, including water and nutrient availability. Rice yield is determined by numbers of panicles per area, number of spikelet per panicle, $\%$ of filled grains per panicle and weight of 1000 grains (kernel weight). In this experiment showed that Inpari 43 has 124.57 panicles/clump, which was the highest compared to other varieties, and the lowest was Inpari 41. However, number of filled grain and kernel weight of Inpari 43 was relatively low compared to Inpari 31 . Kernel weight is largely determined by genetic factors. Therefore, based on these yield components, Inpari 31 had the highest crop yield, i.e. 4.84 t/ha, followed by Inpari 39 (4.78 t/ha) and Inpari 42 (4.64 t/ha). 
Table 2. Growth components of various varieties Olo-Oloho Village, Uepai District, Konawe Regency in the first planting season

\begin{tabular}{|c|c|c|c|c|}
\hline \multirow[t]{2}{*}{ Varieties } & \multicolumn{2}{|c|}{$\begin{array}{l}\text { Plant height } \\
\text { (cm) }\end{array}$} & \multicolumn{2}{|c|}{ Number of tillers } \\
\hline & 30 DAP & 75 DAP & 30 DAP & 75 DAP \\
\hline Inpari 31 & $58.07 \mathrm{ab}$ & $103.00 \mathrm{~b}$ & $9.00 \mathrm{bc}$ & $14.50 \mathrm{ab}$ \\
\hline Inpari 34 & $53.33 \mathrm{~b}$ & $123.33 \mathrm{a}$ & $9.83 \mathrm{ab}$ & $13.70 \mathrm{~b}$ \\
\hline Inpari 35 & $59.07 \mathrm{a}$ & $102.93 \mathrm{~b}$ & $10.53 \mathrm{a}$ & $14.87 \mathrm{ab}$ \\
\hline Inpari 38 & $55.40 \mathrm{ab}$ & $94.77 \mathrm{c}$ & $9.03 \mathrm{bc}$ & $11.00 \mathrm{c}$ \\
\hline Inpari 39 & $54.10 \mathrm{ab}$ & $101.93 \mathrm{~b}$ & $9.67 \mathrm{ab}$ & $15.10 \mathrm{ab}$ \\
\hline Inpari 41 & $58.70 \mathrm{a}$ & $96.57 \mathrm{bc}$ & $9.53 \mathrm{ab}$ & $15.40 \mathrm{ab}$ \\
\hline Inpari 42 & $57.33 \mathrm{ab}$ & $97.23 \mathrm{bc}$ & $7.80 \mathrm{c}$ & $13.97 \mathrm{~b}$ \\
\hline Inpari 43 & $57.53 \mathrm{ab}$ & $96.53 \mathrm{bc}$ & $9.37 \mathrm{ab}$ & $16.10 \mathrm{a}$ \\
\hline Mekongga & $54.37 \mathrm{ab}$ & $100.43 \mathrm{bc}$ & $9.50 \mathrm{ab}$ & $13.40 \mathrm{~b}$ \\
\hline
\end{tabular}

Note: The numbers followed by the same letter in the same column show a significant difference according to the BNT test at the level of 0.05

DAP : days after planting

Table 3. Yield components of various rice varieties in the first planting season in Olo-Oloho Village, Uepai District, Konawe Regency

\begin{tabular}{|c|c|c|c|c|c|}
\hline Varieties & $\begin{array}{c}\text { Panicle } \\
\text { length (cm) }\end{array}$ & $\begin{array}{c}\text { Number of } \\
\text { panicles/ } \\
\text { clump }\end{array}$ & $\begin{array}{c}\text { Number of } \\
\text { filled grain/ } \\
\text { panicle (grain) }\end{array}$ & $\begin{array}{c}\text { Weight 1000 } \\
\text { grains (g) }\end{array}$ & $\begin{array}{c}\text { Yield - } \\
\text { dry grain (t/ha) }\end{array}$ \\
\hline Inpari 31 & $26.97 \mathrm{a}$ & $104.66 \mathrm{bcd}$ & $105.93 \mathrm{a}$ & $32.67 \mathrm{~b}$ & $4.83 \mathrm{a}$ \\
\hline Inpari 34 & $25.80 \mathrm{a}$ & $117.53 \mathrm{ab}$ & $88.20 \mathrm{bc}$ & $31.67 \mathrm{bc}$ & $3.03 \mathrm{e}$ \\
\hline Inpari 35 & $23.90 \mathrm{~b}$ & $91.87 \mathrm{~d}$ & $71.73 \mathrm{c}$ & $34.67 \mathrm{a}$ & $4 \mathrm{~cd}$ \\
\hline Inpari 38 & $22.86 \mathrm{bc}$ & $98.47 \mathrm{bcd}$ & $108.13 \mathrm{a}$ & $27.67 \mathrm{e}$ & $4.06 \mathrm{bcd}$ \\
\hline Inpari 39 & $23.37 \mathrm{bc}$ & $114.93 \mathrm{abc}$ & $77.20 \mathrm{~b}$ & $30.00 \mathrm{~cd}$ & $4.78 \mathrm{a}$ \\
\hline Inpari 41 & $22.60 \mathrm{bc}$ & $97.07 \mathrm{~cd}$ & $72.00 \mathrm{c}$ & $31.00 \mathrm{bcd}$ & $3.56 \mathrm{de}$ \\
\hline Inpari 42 & $23.57 \mathrm{~b}$ & $100.07 \mathrm{bcd}$ & $108.93 \mathrm{a}$ & $29.67 \mathrm{~d}$ & $4.64 \mathrm{ab}$ \\
\hline Inpari 43 & $23.40 \mathrm{~b}$ & $124.57 \mathrm{a}$ & $93.07 \mathrm{ab}$ & $25.67 \mathrm{f}$ & $4.50 \mathrm{abc}$ \\
\hline Mekongga & $21.67 \mathrm{c}$ & $86.83 \mathrm{~d}$ & $79.33 \mathrm{bc}$ & $30.67 \mathrm{~cd}$ & $3.64 \mathrm{~d}$ \\
\hline
\end{tabular}

Note: The numbers followed by the same letter in the same column show a significant difference according to the BNT test at the level of 0.05

In the second period the experiment was done in Lalosabila Village, Wawotobi District, Konawe Regency. Table 4 showed data of the yield components observed. Rice growth and its yield in the second planting season was better than the first planting season, including number of filled grain. However the kernel weight was lower than the first planting season. The crop yield was higher compared to the firs planting season. The rice yield ranged from $4.27 \mathrm{t} / \mathrm{ha}$ to $8.13 \mathrm{t} / \mathrm{ha}$, where the highest rice yield $(8.13 \mathrm{t} / \mathrm{ha})$ was reached by Inpari 43. This higher yield may be due to the better environmental conditions. In the second planting season the rainfall was lower, however water irrigation is still sufficient for plant growth. 
Table 4. Yield components of various rice varieties in Lalosabila Village, Wawotobi District,

Konawe Regency in the second planting season

\begin{tabular}{|c|c|c|c|c|c|}
\hline Varieties & $\begin{array}{c}\text { Panicle } \\
\text { length (cm) }\end{array}$ & $\begin{array}{c}\text { Number of } \\
\text { filled grain } \\
\text { /panicle (grain) }\end{array}$ & $\begin{array}{c}\text { Number of } \\
\text { empty grain / } \\
\text { panicle (grain) }\end{array}$ & $\begin{array}{c}\text { Weight 1000 } \\
\text { grains (g) }\end{array}$ & $\begin{array}{c}\text { Yield - dry } \\
\text { grain (t/ha) }\end{array}$ \\
\hline Inpari 31 & $25.00 \mathrm{~b}$ & $122.80 \mathrm{~b}$ & $16.53 \mathrm{bc}$ & $24.33 \mathrm{c}$ & $5.97 \mathrm{bc}$ \\
\hline Inpari 34 & $26.73 \mathrm{a}$ & $97.66 \mathrm{c}$ & $22.06 \mathrm{a}$ & $25.67 \mathrm{~b}$ & $6.27 \mathrm{bc}$ \\
\hline Inpari 35 & $24.40 \mathrm{~b}$ & $107.33 \mathrm{c}$ & $19.40 \mathrm{ab}$ & $27.83 \mathrm{a}$ & $6.73 \mathrm{~b}$ \\
\hline Inpari 38 & $24.87 \mathrm{~b}$ & $96.53 \mathrm{c}$ & $16.66 \mathrm{bc}$ & $27.33 \mathrm{a}$ & $4.27 \mathrm{e}$ \\
\hline Inpari 39 & $22.93 \mathrm{~cd}$ & $95.86 \mathrm{~cd}$ & $14.33 \mathrm{bc}$ & $27.36 \mathrm{a}$ & $5.43 \mathrm{~cd}$ \\
\hline Inpari 41 & $23.13 \mathrm{c}$ & $83.40 \mathrm{~d}$ & $15.06 \mathrm{bc}$ & $28.00 \mathrm{a}$ & $4.57 \mathrm{de}$ \\
\hline Inpari 42 & $22.33 \mathrm{de}$ & $135.4 \mathrm{ab}$ & $12.60 \mathrm{c}$ & $22.33 \mathrm{~d}$ & $7.93 \mathrm{a}$ \\
\hline Inpari 43 & $22.00 \mathrm{e}$ & $142.20 \mathrm{a}$ & $17.06 \mathrm{zbc}$ & $22.00 \mathrm{~d}$ & $8.13 \mathrm{a}$ \\
\hline Mekongga & $24.53 \mathrm{~b}$ & $99.06 \mathrm{c}$ & $12.60 \mathrm{c}$ & $25.33 \mathrm{bc}$ & $5.30 \mathrm{cde}$ \\
\hline
\end{tabular}

Note: The numbers followed by the same letter in the same column show a significant difference according to the BNT test at the level of 0.05

\subsection{Pest and disease}

During the experiment we found three pests and blast that attacked the rice plants, namely steam borer, bug, Cnaphalocrosis medinalis, and blast (Table 5). These pests and diseases are commonly found in the rice planting area. The attack intensity of stem borer and bug tended to increase from 30 DAP to 75 DAP. The attack intensity of stem borer at 30 DAP ranged $3.10 \%$ (Mekongga) to $9.79 \%$ (Inpari 42). At 75 DAP the attack intensity of this pest increased, ranges $16.33 \%$ (Mekongga) to $27.03 \%$ (Inpari 31). However, this attack did not reduce rice yield significantly. Similar trend also found on bug attack intensity. The intensity of attack of Cnaphalocrosis medinalis tended to decrease from 30 DAP to 75 DAP. Blast also found in the field, however the blast attack intensity was relatively low at $30 \mathrm{DAP}$, and was not found at 75DAP.

Table 5. Intensity of attack (\%) of major pests and diseases at 30 and 75 DAP in Olo-Oloho Village, Uepai District, Konawe Regency in the first plating season

\begin{tabular}{|c|c|c|c|c|c|c|c|c|}
\hline \multirow{2}{*}{ Varieties } & \multicolumn{9}{|c|}{ Major pests } & \multicolumn{2}{|c|}{ Blast } \\
\cline { 2 - 10 } & \multicolumn{2}{|c|}{ Stem Borer } & \multicolumn{2}{|c|}{ Bug } & $\begin{array}{c}\text { Cnaphalocrosis } \\
\text { medinalis }\end{array}$ & \multicolumn{2}{|c|}{} \\
\hline & $\begin{array}{c}\mathbf{3 0} \\
\text { DAP }\end{array}$ & $\begin{array}{c}\mathbf{7 5} \\
\text { DAP }\end{array}$ & $\begin{array}{c}\mathbf{3 0} \\
\text { DAP }\end{array}$ & $\begin{array}{c}\mathbf{7 5} \\
\text { DAP }\end{array}$ & $\begin{array}{c}\mathbf{3 0} \\
\text { DAP }\end{array}$ & $\begin{array}{c}\mathbf{7 5} \\
\text { DAP }\end{array}$ & $\begin{array}{c}\text { 30 } \\
\text { DAP }\end{array}$ & $\begin{array}{c}\mathbf{7 5} \\
\text { DAP }\end{array}$ \\
\hline Inpari 31 & 4.67 & 27.03 & 5.17 & 8.42 & 32.37 & 13.60 & 0.26 & 0.00 \\
\hline Inpari 34 & 7.07 & 21.00 & 10 & 7.00 & 26.33 & 7.70 & 0.23 & 0.00 \\
\hline Inpari 35 & 4.4 & 14.10 & 5.8 & 5.07 & 30 & 11.33 & 0.27 & 0.83 \\
\hline Inpari 38 & 5.1 & 17.00 & 7.67 & 9.20 & 36 & 15.67 & 0.63 & 0.00 \\
\hline Inpari 39 & 5.43 & 24.67 & 4.99 & 8.60 & 26.33 & 13.00 & 4.83 & 0.00 \\
\hline Inpari 41 & 9.64 & 26.97 & 8.26 & 5.53 & 21.80 & 12.63 & 0.73 & 0.00 \\
\hline Inpari 42 & 9.79 & 23.13 & 8.41 & 7.67 & 27.13 & 12.76 & 0.33 & 0.00 \\
\hline Inpari 43 & 6.71 & 18.43 & 7.12 & 4.53 & 30.85 & 10.66 & 0.00 & 0.00 \\
\hline Mekongga & 3.10 & 16.33 & 6.33 & 6.67 & 26.67 & 15.33 & 2.60 & 0.00 \\
\hline
\end{tabular}

\section{Conclusions}

Our finding shows that growth and yield of rice was determined by crop genetics, which shown by crop variety. The growth and yield of rice was better in the second planting season than the first planting season. In the first planting season Inpari 31 had the highest 
yield of $4.83 \mathrm{t} / \mathrm{ha}$, while in second planting season Inpari 43 variety had the highest yield of $8.13 \mathrm{t} / \mathrm{ha}$.

Acknowledgments. This research was funded by DIPA AIAT of Southeast Sulawesi 2017, Number: SP DIPA-018.09.2.567702/2017. We would like to thank the Muslims (Fellow Agricultural Extension Officers, Uepai District, Konawe District), who took part and helped. The same is conveyed to those who have been willing to read and review this article.

\section{References}

1. BPTPH of Southeast Sulawesi, Annual Report of UPTD BPTPH Southeast Sulawesi Province Fiscal Year 2012 (Center for Food Crops and Horticulture Protection, 2013)

2. Samrin, M.T. Ratule, Types and attacks of pests and diseases of rice in Konawe Regency, Southeast Sulawesi, Paper presented at the National Seminar on LocationSpecific Agricultural Week, 21-22 November 2013, Kendari, Sulawesi Tenggara (2013)

3. BPTPH of Southeast Sulawesi, The state of pest attacks and their control on food crops for the 2016/2017 OKMAR period (Food Crops and Horticulture Protection Center, 2016)

4. Food Crops and Animal Husbandry Department of Southeast Sulawesi, Agricultural Innovation Support to increase the Crop Index, Paper presented at the FGD of Planting Index Improvement at Southeast Sulawesi AIAT, 13 December 2017, Food Crops and Livestock Service Office of Southeast Sulawesi Province (2017)

5. Department of Agriculture and Livestock of Southeast Sulawesi, Report of the Agriculture Service of Southeast Sulawesi Province 2014 (Kendari, Sulawesi Tenggara, 2015)

6. M.A. Mustaha, M.T. Ratule, Suharno, A.R. Sery, Z.A. Abidin, C. Nugroho, D. Raharjo, Hilman, Musyadik, Fathnur, Taproni, Assistance in SL-PTT planting calendar in Southeast Sulawesi. Final report of activities for fiscal year 2013 (Southeast Sulawesi Agricultural Technology Study Center, Agricultural Research and Development Agency, Ministry of Agriculture, 2013)

7. M.A. Mustaha, M.T. Ratule, M. Asaad, Suharno, A.R. Sery, M. Rusman, Sjamsiar, Z.A. Abidin, C. Nugroho, D. Raharjo, Dahya, Asmin, A. Sulle, Baharudin, Rusdin, Imran, Hilman, Samrin, Musyadik, Sapiuddin, Taproni, Operationalization of an integrated planting calendar cluster in Southeast Sulawesi. Final report on activities for the 2014 fiscal year (Southeast Sulawesi Agricultural Technology Study Center, Agricultural Research and Development Agency, Ministry of Agriculture, 2014)

8. Abidin, Z. Hilman, Suharno, M. Rusman, M.A. Mustaha, Dahya, M.T. Ratule, Identification of site-specific technology requirements for Southeast Sulawesi. Report on Assessment Results at AIAT Southeast Sulawesi (Agricultural Research and Development Agency, Ministry of Agriculture, 2014)

9. I. Las, E. Surmaini, Climate variability and climate change in national agricultural production systems: Impacts and challenges, in Proceedings of the National Seminar on National Rice Research Results 2010, The Indonesian Center for Rice Research. Agricultural Research and Development Agency, Ministry of Agriculture (2011)

10. S.H. Ou, Rice Disease (Commonwealth Mycological Institute, Kew Surrey, England, 1985)

11. D. Raharjo, C. Nugroho, M.A. Mustaha, M. Asaad, A.R. Sery, Rusdin, Samrin, S. Doni, Study of blast disease control in supporting the increase in lowland rice production in Southeast Sulawesi. Final Report of 2015 Activities (Center for the 
Assessment of Agricultural Technology in Southeast Sulawesi, Agricultural Research and Development Agency, Ministry of Agriculture, 2015)

12. Santoso, A. Nasution, Selection of breeding lines for different blast resistance, in Proceedings of the 2010 National Rice Research Results National Seminar, Agricultural Research and Development Agency, Ministry of Agriculture, (2011)

13. Harahap, Silitongga, Improvement of Rice Varieties Book 2 (Center for Agricultural Research and Development, Bogor, 1993)

14. J. Sularno, Handoyo, Nurhalim, The Role of New Superior Variety Technology Innovations on Increasing Farmers' Income, in Proceedings of the National Seminar on Farmer Empowerment through Location-specific Technological Innovations, 91-96, Book I, BB2TP, STTP Magelang, ISBN.978-979-98579-7-2 (2011) 